\section{Collecting and Examining Beach Sand: Getting Started}

Jim Millette, Thom Hopen and Rich Brown, MVA, Inc

Grains of sand collected from the beach may be examined for a number of reasons. From the youngster who first peers at a handful of beach sand under a magnifying glass to see the various shapes and colors to the sedimentologist who studies sand grains for clues to the questions of plate tectonics, the collection and examination of sand can be a fascinating activity. Dr. Oliver $\mathrm{H}$. Howe, in an interesting article published in 1946, remarked of one sand sample that under a low power magnifier the various colors of garnet grains contrasted strikingly with the black grains of magnetite, green of epidote and the brilliant grains of quartz. To him a sample of sand was a beautiful collection of minerals in miniature. In a chapter of the Particle Atlas on the determination of geographical origin of dust samples, Skip Palenik cites several examples of how the mineral identity, particle shape, size, and surface texture of sand grains were used to pinpoint a geographic location from which a sample came. ${ }^{2}$ For Skip Palenik the microscopic examination of sand is an important forensic tool. Dr. Raymond Siever in an excellent book entitled Sand, published in 1988, describes how the mineral compostion, along with the shape of grains of sand can be used as a diagnostic tool to understand the dynamics of the earth's surface. ${ }^{3}$ To Dr. Siever a sand sample is a geological history book. Although the collection and examination of sand can involve a serious consideration of mineralogy, geographic origin or geologic history, it can also be collected and examined for the fun and wonder of it.

Because sand is technically a collection of particles in the size range $0.06 \mathrm{~mm}$ and $2 \mathrm{~mm}$ it is perfectly suited to be examined with a stereo microscope. Individual grains can be picked for further study under the polarized light microscope (PLM) or scanning electron microscope (SEM). Sand is a product of a number of rock degradation processes such as erosion by wind and water, glacial grinding and the action of ocean waters. The natural occurrence of sand throughout the world in a wide variety of forms provides a near endless source of samples for the microscopist. Although many people have stùdied sand grains for a variety of reasons there are few general books on the subject. There is, for instance, no atlas of beach sands from around the world. This article provides some basic information about collecting and analyzing sand, as well as a review of some of the literature available with notes on illustrations or examples of sands from specific locations.

\section{EQUIPMENT}

Beach sands have been collected in practically every container imaginable. We have found ziplock plastic bags and $35 \mathrm{~mm}$ film canisters to be most useful. Although documentation of the conditions under which the sand was collected can be very extensive, the crucial information for our collection includes the location of the beach area, the time and date of collection and the name of the collector. The location on the beach is also important; dune, shore area, or beach, and distance from the water line. An overall appreciation of the collection of beach sand grains in the sample can be gained by looking through a hand lens or better through at least a $5 X$ magnifier. The interesting crystal shapes of some of the grains can best be observed under the stereo microscope or scanning electron microscope.

\section{BOOKS AND ARTICLES TO START WITH}

Although many people have studied sand grains for a variety of reasons, there does not appear to be any introductory book which describes beach sands and shows the many types of grains that exist. Unfortunately for the beginner, books with illustrations, especially color photographs which would be most interesting, are few. There are, however, several books and articles which help a beginner gain a sense of the many interesting aspects of collection and examining sand.

The book entitled Sand by Raymond Siever is an excellent resource book for a sand collector. Although some knowledge of scientific terms is

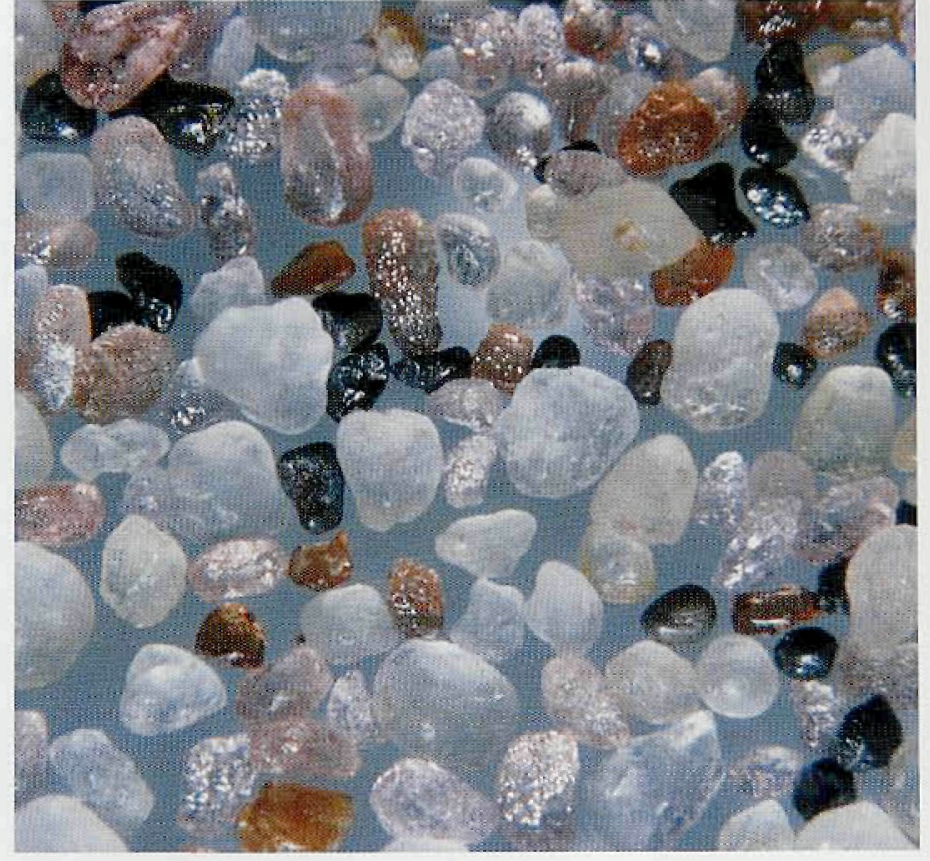

Picture Rocks from Chapel Beach, Lake Superior, MI (26X)

helpful in fully understanding some of the technical issues described in the text, anyone who has looked through a low-power microscope at grains of sand can appreciate the color photographs of sand grains that serve as examples to various aspects of the sand. Written in the style of the journal Scientific American, the book provides full explanations of where sand comes from, how sand travels, and ultimately how the study of sand grains helps in reading plate tectonics.

For the person getting started in collecting sands the color photographs of groups of sand grains are particularly interesting. Pure quartz sand from Belize, South America is used to illustrate grains which are angular, showing little evidence of rounding during transport. Similarly, the angular, olivine-rich sand of South Point, Hawaii, is contrasted with rounded quartz from Florida. Two calcium carbonate sands are also shown. The one from Cooper's Bay, New Zealand is mostly shell fragments. In contrast, the other calcium carbonate sand is composed mainly of oolites (rounded shapes), cemented slightly by calcium carbonate precipitated between the grains.

The roughly rectangular shapes typical of gypsum grains and the rounding caused by abrasion during wind transport are illustrated with a microscopical view of a sample from the gypsum sand dunes of White Sands, New Mexico. The fragments of basalt and grains of olivine and pyroxene from black volcanic rock sands are shown to help depict the fragmentation and weathering of basaltic lavas in Hawaii.

In addition to the photographs, page 58 contains a clear illustration showing typical shapes of minerals forming common sand grains, quartz with its equant or spherical particles as well as blades and pencils, feldspar grains with traces of cleavage planes, mica sheets, and the rough irregular forms of amphiboles and pyroxenes. As indicated, the book is an excellent reference for learning about several aspects of sand examination. It was found in the public library.

The article by Howe which appeared in a 1946 edition of Micro-Notes is an interesting and perhaps inspiring article on the analysis of sand. Although a bit rambling in style, the keen interest of $\mathrm{Dr}$. Howe in the analysis of sand is clearly conveyed. He does provide some analytical results from specific locations. Howe reported that sand from Topsham, Maine, consisted wholly of mica. He also notes that in Yellowstone Park there is an source of obsidian sand (a natural volcanic glass) which is black in color and has conchoidal fracture

Some popular field guides to rocks and minerals have sections on sand. The Golden Book* indicates that although most common sand is of the quartz variety, there are also coral sands, gypsun sands, and sands rich in magnetite, monazite, garnet, ilmenite, and rutile. Other guides have general information 


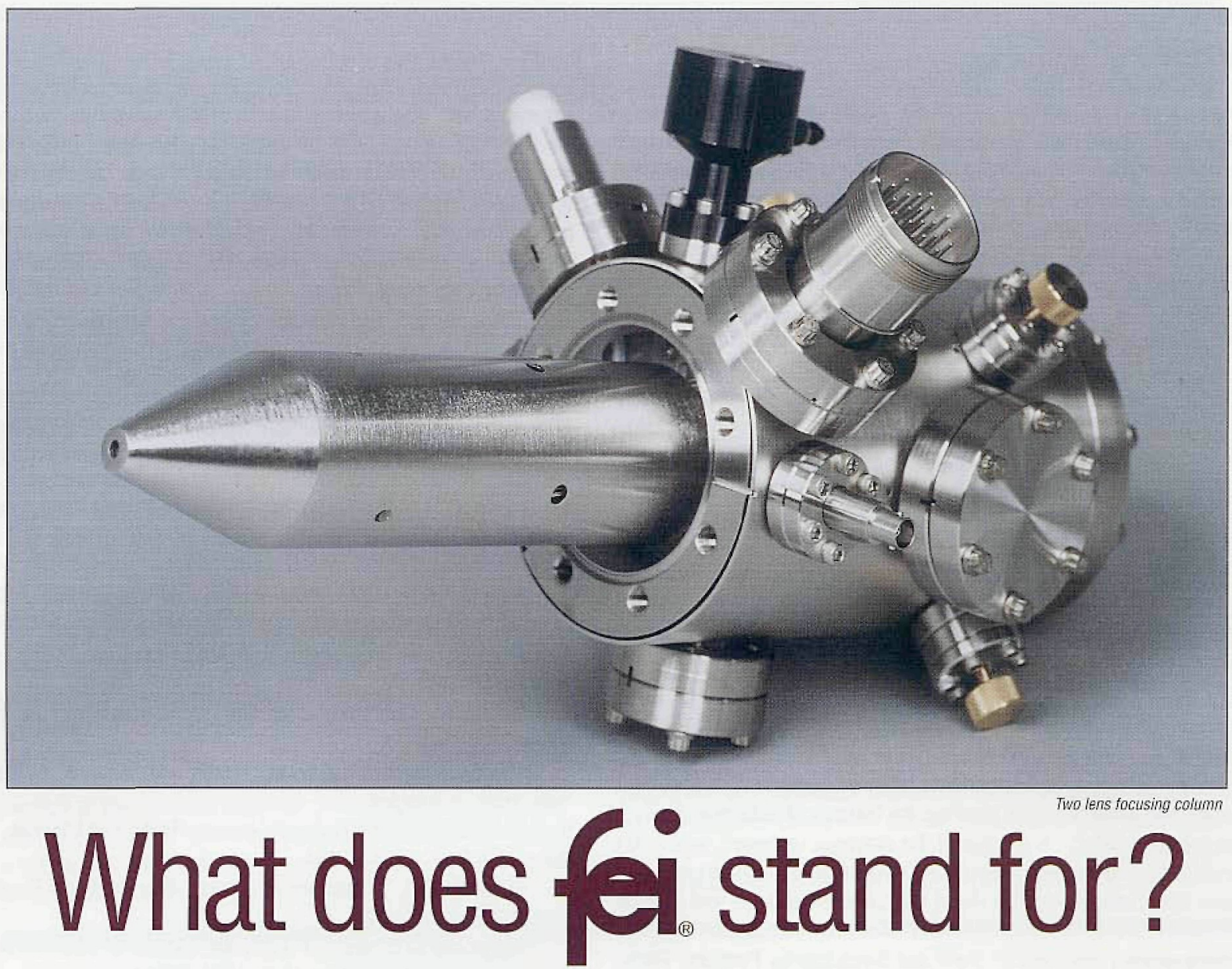

Our compact, UHV, field emission columns are used by researchers world wide. Innovative electrostatic optics and dedicated electronics allow you to integrate a high current density electron or ion column into most vacuum systems. FEI also supplies researchers with other specialized products...

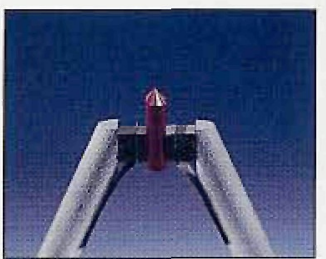

$\mathrm{LaB}_{6}$ an $\mathrm{CeB}_{6}$ Cathodes

FEl's Mini-Vogel Mount, the first universally compatible long-life, high-stability LaBe cathode, provides excellent performance and the best cost-per-use value for installation into your EM systems.

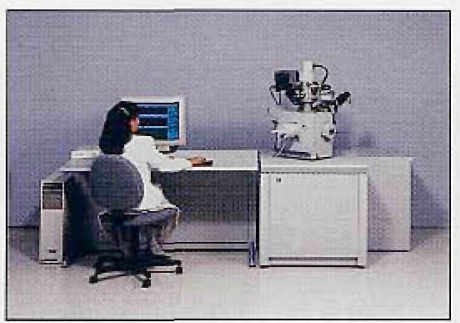

\section{FIB Workstations}

Focused ion beam micromilling workstations range from the 8"-wafer compatible model to the economical 2" small sample model ideal for semiconductor, biological, TEM, and MEMS specimens.

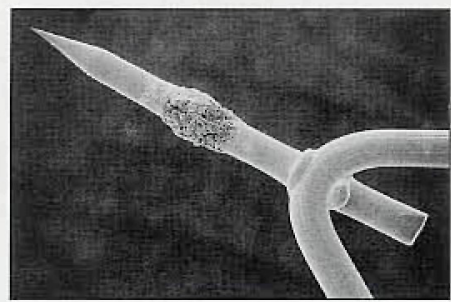

Field Emission Cathodes FEI supplies Schottky field emitters to EM manufacturers worldwide. Schottky emission's high current intensity has established it as the preferred electron source for high resolution SEM, TEM, Auger, ESCA, $E D X$, and lithography.

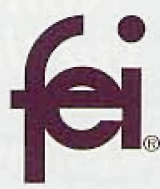

FEl Company

7451 NE Evergreen Parkway

Hillsboro, OR $97124-5830$

(503) 640-7500 Fax (503) 640-7509

email:rsk@feico.com

Now, when you think of FEl, you'll know we are the Specialists in Field Electron and Ion Technology. 
Beach Sand.....Continued from page 18

about colored sands. For instance, a guide by Loomis states that "along some shores of the ocean, there occur 'green sands' which are ordinary quartz sands mixed with the dark green mineral glauconite, which is a potassium iron silicate, forming on the ocean bottom as a result of the action of decaying animal matter on iron-bearing clays and potassium-bearing silicates, like feldspar. This is particularly characteristic of some of the sands along the coast of New Jersey.

The Rock Dictionary ${ }^{6}$ has several entries for colored sands. Black colored sands in beach and alluvial placers are often high in magnetite and ilmenite, but may also contain other dark minerals such as cassiterite, rutile, thorite, betafite, euxenite, columbite, and schorl. Sands rich in green olivine occur in some volcanic regions, such as on the beach at Hansuma Bay, Koto Head area, Oahu, Hawailan Islands. Greensand is the name given to the Atacamite sand from Peru and from the desert of northern Chile. Red-colored beach sand containing much garnet is found in Nome, Alaska. Perhaps the best known white sands are those composed primarily of gypsum which can be found at White Sands National Monument, New Mexico. (It should be noted that the color of individual sand grains can sometimes be misleading in terms of identification as many minerals occur in several colors.)

For the analyst requiring more technical information, it will be necessary to turn to the texts and papers of sedimentologists. The 1938 Manual of Sedimentary Petrography by Krumbein and Pettijohn contains 42 pages describing common minerals found in sedimentary rocks. ${ }^{7}$ The section includes significant diagnostic properties and detrital (single grain) characteristics of each mineral. Although this early edition contains no color illustrations, it does have excellent black and white drawings showing the features of individual grains of most of the minerals listed. A number of the drawings represent grains from English sands (including Cornwall, Yorkshire, Devonshire) while American sands include grains from Lake Erie (Cedar Point) and Lake Michigan as well as other areas

The more recent (1987) text on Sand and Sandstone by Pettijohn, Porter, and Siever, although containing sections useful to the experienced sand analyst, will be a disappointment to the beginning sand collector. ${ }^{\mathrm{P}}$ Unfortunately there are no color photographs and few black and white drawings of individual sand grains. There is one excellent set of scanning electron micrographs showing Amazon Basin river sand grains. Of some interest is an annotated bibliography of sources for the study of sand and sandstone and an interesting section on determining provenance (source) of sand samples.

The McCrone Particle Atlas volumes contain a number of photomicrographs of individual mineral grains which can be found in various sands. ${ }^{9}$ Only a few, however, are identified as to source: rutile beach sand from Australia (p. 398) and grains found in the red rain of London which originated from the North African Sahara desert (p.560). The chapter on the determination of geographical origin of dust samples by Skip Palenik contains an interesting story about the examination of a Japanese beach sand and other information on the use of sand examination for forensic studies.

Photomicrographs of how individual grains of garnet, epidote, hornblende, kyanite, rutile, sphene (titarite), tourmaline, and zircon appear under the light microscope can be found in Schoile's color guide of sandstones and associated rocks. ${ }^{10}$ This excellent atlas of sandstones in thin section published by the American Association of Petroleum Geologists contains four pages of single crystal micrographs and a selected detrital grain bibliography.

The articles and books described in this brief paper are some of the more readily available references. In future articles we hope to describe the analysis of specific sands and will refer to other books which contain analytical notes.

One of the best children's books on sand is one by Sally Carturight entitled Sand. This short book describes many of the properties of the material and gives several interesting activities to help children learn about sand. ${ }^{11}$ Although well written, the book did not appeal to three children ages 10,7, and 4 as much as the color photographs of sand grains found in the other "Sand" books by Siever.

By comparison with beach sand, the examination of commercial sand which contains primarily quartz, is less interesting to the general sand collector. Industrial sands which tend to be nearly pure quartz are materials for more specialized studies. Approximately $40 \%$ of industrial sand is used as the principle raw material in glassmaking. ${ }^{12}$ Two types are used white sand in the manufacture of fint or white glass and yellow sand for the manufacture of colored glass. The major difference in the two sands involves the iron and chrome oxide content, with the yellow sand having six times the $\mathrm{Fe}_{2} \mathrm{O}_{3}$ and ten times the $\mathrm{Cr}_{2} \mathrm{O}_{3}$ of white sand. Although the white sand is over $99 \% \mathrm{SiO}_{2}$ and the yellow sand over $98.5 \% \mathrm{SiO}_{2}$ the microscopist may find grains of a number of contaminants. Refractory impurities that have been found in some glassmaking sand include: sillimanite, kyanite, andalusite, zircon, spinel, corundum, chromite and kaolin.

The collection and analysis of sand is an interesting and educational activity. Collectors wishing to trade samples or correspond about interesting sand grains should write to any of the authors.

Acknowledgement: The authors would like to acknowledge the helpful comments of Dr. Pamela Gore, a sedimentologist teaching in Atlanta.

Howe, O.H. "The Formation, Composition, and Transportation of Sand," Micro-Notes, State Microscopical Society of Illinois, 1946, (2)2:19-22, (2)3.3135.

2. Palenik, S.J., "The Determination of Geographical Origin of Dust Samples," in The Particle Atlas Vol. V, McCrone, W.C, J.G. Delly, S.J. Palenik, Ann Arbor Science Publishers, Ann Arbor, Michigan, 1973, pp. 1347-1361. (now out of print).

3. Siever, R., Sand Sci. Amer. Libr., W.H. Freeman, New York, 1988, 237 pages.

4. Zim, H.S. and P.R. Shaffer, Rocks and Minerals, Golden Press, New York, 1957, 153 pages.

5. Loomis, F.B., Field Book of Common Rocks and Minerals, G.P. Putnam's Sons, New York, 1923, p. 204.

6. Mitchell, R.S., Dictionary of Rocks, Van Nostrand Reinhold Co., New York, 1985, pp. 86,174

7. Krumbein, W.C. and F.J. Pettijohn, Manual of Sedimentary Petrography, Appleton-Century-Crofts, New York, 1938, 549 pages.

8. Pettijohn, F.J., P.E. Porter, R. Siever, Sand and Sandstone, SpringerVerlag, New York, 1987, 553 pages

9. McCrone, W.C. and J.G. Delly. The Particle Atlas Vol.2, Ann Arbor Sciences Publishers, Ann Arbor, Michigan, 1973. (now out of print).

10. Scholle, P.A., Memoir 28, A Color I/lustrated Guide to Constituents, Textures, Cements, and Porosities of Sandstone and Associated Rocks, The Amer. Assoc. Petroleum Geologists, Rodgers Litho, Tulsa, Oklahoma, 1979 pp. $57-62$

11. Cartwright, S., Sand, Coward, McCann, and Geohegan, Inc., New York, 1975, 36 pages.

12. Mills, H.N., "Glass Raw Materials" in Lefond, S.J. (ed), Industrial Minerals and Rocks, Soc. Mining Eng. New York, 1983, 5ed (1):339-347.

Reprinted from Micro-Notes II - a publication of the State Microscopical Society of Illihois

Diffraction Simulation \& Analysis Software for the Macintosh

Microscopist ${ }^{\text {im }}$

Upgrades / Demos

Now Available via the Internet!

http://www.Rt66.com/ virtlabs/

VRTUAL LABORATORIES tel: 505-828-1640 • fax: 505-822-9759 
Use this form to register at reduced rates. Payment can be by check (U.S. funds, payable to "MSA" at a U.S. bank), money order, or credit card (Visa/MasterCard only). With a credit card you can register by phone, 508-563-1155; toll free, 800-538-3672 or fax, 508-563-1211. Or mail the form to Microscopy \& Microanalysis '96, 4 Barlows Landing Rd., Suite 8, Pocasset, MA 02559. Do not send payment separately from the form. Purchase orders are not accepted. Payment for more than one registrant can be combined in a single check, but use a separate form for each registrant, including social guests (it may be photocopied). Receipts will be sent promptly.

The rates are valid only for forms received by July 15 . It is not enough for the form to have a postmark of that date. The rates after $J u l y 15$ are indicated on the form. Refund requests will be honored, less a $\$ 40$ handling fee, only if received in writing by August 9 , 1996 . MSA's Federal $1 D$ and tax-exempt number is 116-042-333.

All registrations include admission to scientific sessions, commercial exhibits, and the Sunday evening reception. Proceedings are included only with Full registrations.

Title (Mr., Ms., Dr. only, please):

Name:

Address:

Zip:

Phone: ( )

Fax: ( )

Email:

Type or print your name and affiliation as you would like them to appear on your registration badge. (No titles, please. 30 characters maximum for each line.)

Name:

University/company:

Check (to "MSA") enclosed? $\square$

Credit card number (Visa/MasterCard only):

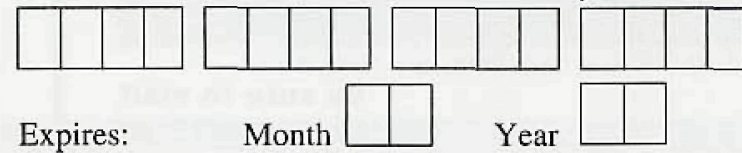

Signature:

Print name on card:

For office use only.
Registration fee (check only one)

$\$$

$\square \quad$ Full - MSA-MAS-MSC/SMC member. $\$ 190$ (after July 15, \$250)

$\square \quad$ Full - non-member. $\$ 275$ (after July 15, \$325)

$\square \quad$ Student. $\$ 60$ (after July 15, \$90)

Note; Student Registration is only for Student Members of a sponsoring Society. Others may register at the student rate but must include with this form a letter from their advisor attesting to bona fide full-time student status.

$\square \quad$ Emeritus. $\$ 60$

(for Emeritus members only)

(after July 15, \$90)

$\square \quad$ Social guest (use separate form for each). $\$ 60$ (after July 15, \$90)

$\square \quad$ One day. $\$ 75$. Specify day: (after July 15, \$75)

$\square \quad$ Two day. $\$ 150$. Specify days: (after July 15, \$150)

HRFESEM Pre-Meeting Workshop $\$ 10$ $\$$

Short Course fees

96-01, 96-02 members $\$ 120$, others $\$ 140$

$\$$ (after July 15, \$180 for all)

96-03, 96-04, 96-05 members $\$ 60$, others $\$ 70$ (after July 15, $\$ 90$ for all)

Specify Course Number(s): 96-0

Social Events fees

Wednesday River Cruise

Gabbert Raptor Center

- @ $\$ 35$

Mayo Clinic Tour (Q) $\$ 8$

Additional Reception tickets

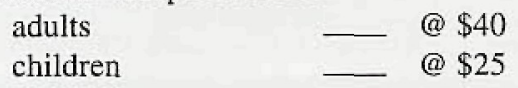

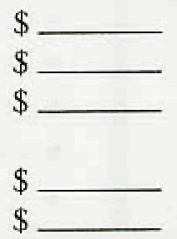

Please note: All Social Events are non-refundable except if the event is cancelled.

Additional Proceedings __ @ $\$ 50$

$\$$

Direct shipping of Proceedings

$\$$

(to arrive after Meeting)

Contiguous U.S. \$15, Canada $\$ 20$.

TOTAL PAYMENT:
$\$$ 